\title{
PERCEPÇÃO DE BARREIRAS DA CARREIRA EM ADOLESCENTES PORTUGUESES
}

\section{[Perception of Career Barriers in Portugueses adolescents]}

\author{
Paulo Cardoso
}

(Universidade de Évora)

Contacto:

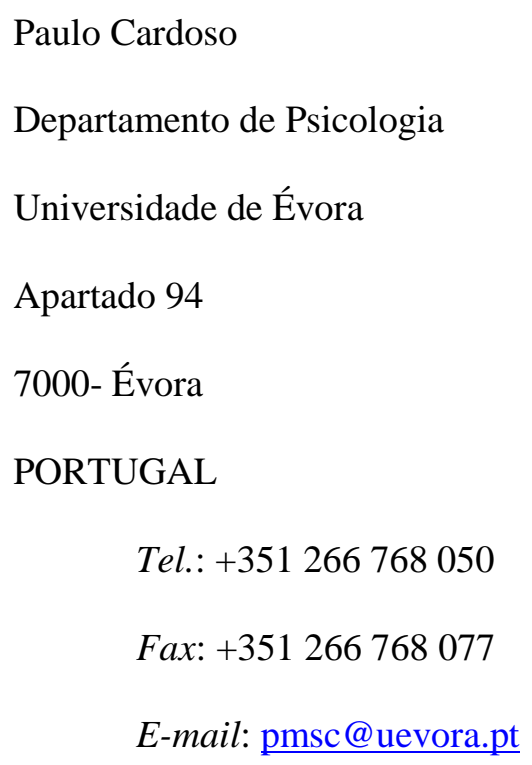

\section{Publicação:}

Cardoso, P. (2007/2008). Percepção de barreiras da carreira em adolescentes portugueses [Perception of Career Barriers in Portugueses adolescents]. Revista Portuguesa de Psicologia, 40, 141-161. 


\title{
Resumo
}

Este estudo teve como objectivo analisar a percepção de barreiras da carreira num grupo de adolescentes portugueses. A 1005 estudantes, 488 frequentando o $9^{\circ}$ ano (idade média de 14.5 anos) e 517 o $12^{\circ}$ ano de escolaridade (idade média 17.5 anos), foi dado a preencher um questionário de dados demográficos e o Inventário de Percepção de Barreiras - Revisto (IPBC-R). Os resultados obtidos evidenciam que a generalidade dos participantes considera os numerus clausus no acesso ao ensino superior, a precariedade dos vínculos laborais ou a falta de emprego as mais importantes barreiras ao seu desenvolvimento da carreira. Para alguns, acresce a percepção de barreiras específicas ao grupo social de pertença. Os resultados são discutidos tendo em conta as suas implicações para a prática da psicologia vocacional.

Palavras chave: barreiras da carreira, desenvolvimento da carreira, adolescentes.

\begin{abstract}
The purpose of this study was to analyse the perception of career barriers in Portuguese adolescents. Both an inquiry of demographic data and the Perception of Career Barriers Inventory-Revised were administered to a sample of 1005 Portuguese students, 488 from grade 9 (age mean 14.5 years old) and 517 from grade 12 (age mean 17.5 years old). Results reveal that the most important barriers to their career development are: numerus clausus in high school to higher education transition, employment precariousness and unemployment. Participants from particular social groups had also specific perceived barriers to career development. These findings are discussed in terms of their practical implications.
\end{abstract}

Key words: career barriers, career development, adolescents. 